\title{
A nationwide population screening program for diabetes in Brazil
}

\author{
Luciana B. Nucci, ${ }^{1}$ Cristiana M. Toscano, ${ }^{1,2}$ Ana Lourdes M. Maia, ${ }^{2}$ \\ Cláudio D. Fonseca, ${ }^{2}$ Maria Moema B. Britto, ${ }^{2}$ Bruce B. Duncan, ${ }^{1}$ \\ and Maria Inês Schmidt, ${ }^{1}$ for the Brazilian National Campaign for \\ Diabetes Mellitus Detection Working Group ${ }^{3}$
}

Suggested citation

Nucci LB, Toscano CM, Maia ALM, Fonseca CD, Britto MMB, Duncan BB, Schmidt MI, Brazilian National Campaign for Diabetes Mellitus Detection Working Group. A nationwide population screening program for diabetes in Brazil. Rev Panam Salud Publica. 2004;16(5):320-7.

\begin{abstract}
Objectives. In 2001, persons throughout Brazil who were 40 years old or older were invited to participate in community screening for diabetes as part of the Brazilian Ministry of Health's Plan for the Reorganization of Care for Arterial Hypertension and Diabetes Mellitus. This report describes the overall participation rate and positivity rate of the screening campaign, as well as factors associated with the level of participation among the municipalities in Brazil.

Methods. Screening test positivity was defined as a fasting glucose of $\geq 100 \mathrm{mg} / \mathrm{dL}$ or a casual glucose of $\geq 140 \mathrm{mg} / \mathrm{dL}$. Screening data were obtained from the Ministry of Health and were analyzed for each municipality.

Results. Out of the 5561 municipalities in Brazil, 5301 of them (95.3\%) participated and reported results. Of the 30.2 million persons in the target population, 22.1 million of them $(73.0 \%)$ were tested, and 3.5 million of the persons tested $(15.7 \%)$ were positive. Higher odds of a high population participation rate $(\geq 80 \%)$ were seen in municipalities that were of small size (risk ratio $(R R)=5.0$, comparing extremes), were located in the North region of the coun$\operatorname{try}(R R=1.8)$, were located outside of a metropolitan region $(R R=1.4)$, and had a higher proportion of their population who had completed elementary school $(R R=1.2)(\mathrm{P}<0.05)$. There was a parallel increase in glucose testing nationwide during and immediately after the campaign, presumably in part for diagnostic confirmation of cases identified during screening. Conclusions. The massive response to the campaign attests to the potential that this type of program has to raise diabetes awareness and to set the stage for capacity-building at the primary care level.
\end{abstract}

Key words Diabetes mellitus, mass screening, health promotion, community health services, Brazil.

Federal University of Rio Grande do Sul, School of Medicine, Graduate Studies Program in Epidemiology, Porto Alegre, Rio Grande do Sul, Brazil. Send correspondence to: Luciana Bertoldi Nucci, R. da Granja Julieta, 09 / 34, São Paulo - SP, CEP 04721-060 - Brazil; telephone/fax: +55 115686. 7482; e-mail: lbnucci@terra.com.br

2 Brazilian Ministry of Health, Health Policy Division, Brasília, Distrito Federal, Brazil. (The current affiliation of Cristiana M. Toscano is: Pan American Health Organization, Family and
Community Health, Immunization Unit, Brasília, Brazil.)

3 The Brazilian National Campaign for Diabetes Mellitus Detection Working Group: Secretaria de Políticas de Saúde - Ministério da Saúde: Ana Luiza Vilasbôas, Ana Lourdes Marques Maia, Carlos Alberto Machado, Cláudio Duarte da Fonseca, Cristiana M. Toscano, Elisabeth Kalil Nader, Islene de Araujo Carvalho, Laurenice Pereira Lima, Marco Antonio Mota Gomes, Maria Moema Borges Leal de Britto, Romero Bezerra Barbosa, Tatiana Lotfi de Sampaio, and Vaneide Marcon Cachoeira; Sociedade Brasileira de Diabetes: Adriana Costa e Forti; Instituto de Saúde Coletiva - Universidade Federal da Bahia: Lucélia Magalhães; Programa de Pós-graduação em Epidemiologia — Universidade Federal do Rio Grande do Sul: Bruce Bartholow Duncan, Luciana Bertoldi Nucci, Maria Inês Schmidt, Sotero Serrate Mengue; Departamento de Medicina Social - Faculdade de Medicina de Ribeirão Preto - Universidade de São Paulo: Laércio Joel Franco. 
Type 2 diabetes mellitus is a significant cause of morbidity and mortality worldwide (1). Prevention of diabetes and its complications has become a major public health priority $(2,3)$. A Brazilian countrywide prevalence survey carried out in 1986-1988 demonstrated that the overall diabetes prevalence in the urban population aged 30 and over was $7.6 \%$, with half of these cases being undiagnosed (4). While early detection and treatment of undiagnosed diabetes is intuitively attractive as a strategy for preventing complications of the disease, it has never been evaluated in randomized clinical trials $(5,6)$. As such, official recommendations for screening undiagnosed type 2 diabetes have been made only for high-risk individuals (7-9). Only a few experiences in universal population screening of undiagnosed diabetes have been undertaken (10).

As part of its Plan for the Reorganization of Care for Arterial Hypertension and Diabetes Mellitus (Plano de Reorganização da Atenção à Hipertensão Arterial e ao Diabetes Mellitus) (11), the Brazilian Ministry of Health, in conjunction with state and local health authorities and medical societies, conducted the National Campaign to Detect Suspected Cases of Diabetes Mellitus (Campanha Nacional de Detecção de Casos Suspeitos de Diabetes) in 2001. The Campaign's main purposes were to raise population awareness of diabetes as a public health issue, to screen individuals aged 40 and over for diabetes mellitus by capillary glucose testing, and to increase the ability of the public primary health care service at the municipal level to diagnose diabetes and to provide continuing care for patients with the disease (12).

In Brazil most health care is provided by the country's public Unified Health System (UHS) (Sistema Único de Saúde, or SUS). The UHS provides care to the entire population of Brazil. It is estimated that $75 \%$ of Brazilians use only the UHS services, with the other $25 \%$ also covered by private health care services. Nationwide, there are approximately 65000 UHS primary health care centers in the country's
5561 municipalities. Secondary and tertiary health care services are also part of the UHS. Throughout the country, the UHS services are managed mostly by the municipalities, but the extent of local management varies from municipality to municipality.

This study aims to expand on a preliminary description of the Campaign (13) by describing the percentage of the Brazilian population reached and the percentage identified as screenpositive, as well as factors associated with a higher population participation rate at the municipal level. The study also describes the number of serum glucose, glycated hemoglobin, and two-hour glucose tolerance tests performed in UHS laboratories (which provide services to the primary health care system) during three months around the time of the Campaign in 2001 as compared to the number of tests done during the same months in the previous year.

\section{MATERIALS AND METHODS}

The Campaign was conducted between 6 March and 7 April 2001. Its target population for screening was Brazilian adults aged 40 and over who received care through the country's UHS. To reach this target population, a massive media campaign (television, radio, billboards) was launched to inform adults of the importance of diabetes and the possibility of screening for it at primary health care centers during the days of the Campaign. In addition, prior to the Campaign, a nationwide training course on the diagnosis and management of diabetes in primary care was provided for 13029 health professionals of the UHS primary health care centers.

Efforts were also made to have available certain infrastructure needs so that patient postscreening evaluation and treatment would be available, as part of the Plan for the Reorganization of Care for Arterial Hypertension and Diabetes Mellitus. These efforts included reorganizing services in the primary health care centers in order to better provide services for individuals with diabetes mellitus, strengthening and organizing the referral system, and making available medications for long-term diabetes therapy.

At screening during the Campaign, participants were asked about recent food intake. If they had ingested food during the preceding four hours, this information was noted. Participants were also asked their age and whether they were currently receiving treatment for diabetes or hypertension. Though individuals currently receiving treatment for diabetes were not recruited, they frequently presented during the Campaign, and they were tested. For these persons, the fact that they were currently receiving treatment was recorded on a standardized form that was kept at the local health center.

Using portable meters, glucose screening was performed on fingerstick capillary blood. The test was considered positive if $\geq 100 \mathrm{mg} / \mathrm{dL}$ when fasting (persons who said they had not ingested anything for at least four hours), or if $\geq 140 \mathrm{mg} / \mathrm{dL}$ otherwise. All this information was recorded on the standardized form.

The persons whose screening test results were positive were directed to undergo further diagnostic evaluation. The immediacy and nature of this evaluation was based on the glucose level alteration found at screening. When glucose was $\geq 270 \mathrm{mg} / \mathrm{dL}$, an immediate referral for medical care was made.

Daily counts of the total numbers of tests and of screen-positive tests were recorded at each health center and then aggregated at the municipal level. The municipalities then faxed summaries of this information to the national Ministry of Health. The participation results and the positivity results reported in this article are based on the data compiled by the Ministry of Health, using the summaries sent in by the municipalities.

The Campaign's target population were the estimated 31 million Brazilian individuals aged 40 and over who were receiving health care through the 
UHS. These 31 million persons represented $75 \%$ of the estimated 1999 total of 41.4 million Brazilians aged 40 and over (13).

Brazil has a total of 5561 municipalities, and we obtained data from 5301 of them $(95.3 \%)$. The 260 municipalities that were excluded were made up of 56 municipalities $(1.0 \%)$ that were not part of the reporting system due to their recent creation, $168(3.0 \%)$ that did not provide information on the number of tests performed, 21 ( $0.4 \%)$ that did not provide information about the number of positive test results, and $15(0.3 \%)$ in which the participation rate data were inconsistent. With the exclusion of the population of these 260 municipalities, the target population was reduced to 30.2 million individuals.

Data on social and demographic factors and health service organization characteristics were obtained on-line from DATASUS, a database of the Brazilian Ministry of Health (14-18), and were supplemented with other information from the Ministry of Health.

The participation rate was defined as the total number of capillary glucose tests reported by each municipality, divided by the total number of eligible adults. A high participation rate was defined as being $\geq 80 \%$ (equivalent to the 75th percentile of the distribution). The positivity rate was calculated as the number of positive tests divided by the total number of tests performed, for each municipality.

The correlates of a higher participation rate at the municipal level that we investigated were: region of the country; the extent to which the municipality directly managed the UHS health care services located within that municipality; percentage of the municipality's population registered in the Family Health Program (Programa de Saúde da Família) (15) and in the Community Health Agents Program (Programa de Agentes Comunitários da Saúde) (16); if the municipality was located within a metropolitan region (Brazil has 26 metropolitan regions, with a total of 413 municipalities and 68 million residents) (17); percentage of pop- ulation living in an urban area (14); percentage of all individuals in the municipality who had completed elementary school (8 years of study); and total population of the municipality (14). Municipality and population data were provided by the Brazilian Institute of Geography and Statistics (Instituto Brasileiro de Geografia e Estatística, or IBGE) (18).

The Family Health Program is a UHS strategy intended to improve the effectiveness of primary health care services. It was implemented in Brazil in 1994. Its main objectives are to enhance access to health care services and to increase resolution of common health conditions at the primary level of care. Since its implementation, municipalities have progressively incorporated the strategy into their health care services and increased the proportion of their population covered by the program. Each team includes physicians, nurses, nurse assistants, and community health agents, who provide service to a specified number of families in a geographically defined area. The Community Health Agents Program was implemented prior to the Family Health Program. While the strategies and objectives of the Community Health Agents Program are similar to those for the Family Health Program, the Community Health Agents Program does not include a physician on its team.

We also obtained from the DATASUS database the number of serum glucose, glycated hemoglobin, and two-hour glucose tolerance tests performed in UHS laboratories in 2000 and 2001 (19).

For our analyses, the data extracted from the DATASUS database and the data on the participation rates and the positivity rates that came from the Ministry of Health were exported to an SAS dataset (20) and then merged. The associations that the municipality characteristics had with high participation rates and positivity rates were adjusted through logistic regression. Adjusted odds ratios were corrected in order to better approximate the true relative risk (RR) (21). In these models, the municipality was used as the unit of analysis.

\section{RESULTS}

In total, 22069905 capillary glucose tests were performed, yielding an overall national participation rate of 73.0\% (22 069 905/30 234 853). The participation rate and the positivity rate by region and state are shown in Table 1. Of the 22069905 capillary glucose tests performed, 3474900 of them $(15.7 \%)$ were positive. In two of the states, Pará and Rio Grande do Norte, the participation rate was higher than $100 \%$ of target.

The distribution of social and demographic factors and of health service characteristics for the municipalities is presented in Table 2. Most municipalities were small, partially urbanized, and outside of metropolitan regions. Administratively, most of the municipalities directly managed only outpatient services. With respect to the specific programs for delivering care, most municipalities did not provide care through the Family Health Program, and about half provided care through the Community Health Agents Program.

The municipality characteristics that were related to a high participation rate are shown in Table 3. After adjustment for other characteristics, factors associated with a high participation rate were: being located in the North region $(R R=1.8)$, being located outside a metropolitan region $(R R=1.4)$, having a smaller proportion of the population living in an urban area ( $<25 \%, \mathrm{RR}=1.3 ; \geq 25 \%$ to $<75 \%$, RR = 1.2), having a higher percentage of the population with at least elementary schooling $(\geq 10 \%, \mathrm{RR}=1.2 ; \geq 5 \%$ to $<10 \%$, RR $=1.2$ ), and having a smaller overall population ( $\geq 500000$ inhabitants vs. $<50000$ inhabitants, $R R=0.2$ ).

The age structure of the population was not associated with the participation rate. In addition, neither the municipality characteristics that were related to health services organization (proportion of the population regis- 
TABLE 1. Participation rate and positivity rate (\%) in the National Campaign to Detect Suspected Cases of Diabetes Mellitus, by region and state, Brazil, March-April, 2001

\begin{tabular}{lcc}
\hline \multicolumn{1}{c}{ Region/State } & Participation rate & Positivity rate \\
\hline North region (overall) & 92.7 & 14.0 \\
Acre & 77.0 & 15.2 \\
Amazonas & 62.2 & 11.3 \\
Amapá & 73.9 & 14.9 \\
Pará & 119.6 & 15.7 \\
Rondônia & 92.6 & 11.4 \\
Roraima & 86.0 & 13.9 \\
Tocantins & 96.5 & 14.3 \\
Northeast region (overall) & 81.0 & 16.4 \\
Alagoas & 79.2 & 25.3 \\
Bahia & 77.5 & 16.1 \\
Ceará & 75.5 & 14.2 \\
Maranhão & 79.6 & 17.4 \\
Paraíba & 91.7 & 14.8 \\
Pernambuco & 78.3 & 16.6 \\
Piauí & 85.9 & 14.9 \\
Rio Grande do Norte & 101.2 & 15.8 \\
Sergipe & 84.4 & 19.5 \\
Center-West region (overall) & 83.3 & 16.1 \\
Distrito Federal & 75.3 & 15.0 \\
Goiás & 83.5 & 16.2 \\
Mato Grosso & 75.9 & 18.2 \\
Mato Grosso do Sul & 93.0 & 14.8 \\
Southeast region (overall) & 65.4 & 15.1 \\
Espírito Santo & 94.6 & 11.9 \\
Minas Gerais & 79.0 & 13.5 \\
Rio de Janeiro & 52.1 & 16.0 \\
São Paulo & 62.9 & 16.0 \\
South region (overall) & 73.7 & 16.7 \\
Paraná & 85.8 & 14.4 \\
Rio Grande do Sul & 59.5 & 19.2 \\
Santa Catarina & 84.5 & 16.7 \\
Brazil (overall) & 73.0 & 15.7 \\
\hline
\end{tabular}

tered in the Family Health Program and proportion registered in the Community Health Agents Program) nor the degree of local control over the health care system were associated with the participation rate.

The number of diabetes-related tests performed each month from January 2000 through December 2001 is shown in Figure 1. In general, there was a gradual increase over time in the permonth number of tests. However, a distinct peak in serum glucose testing and in glycated hemoglobin testing performed countrywide occurred in the months preceding, during, and shortly after the Campaign. During March, April, and May of 2001 a total of almost 750000 more serum glucose tests were performed than had been done in the same three months the year before. There was a smaller peak in serum glucose testing in August of 2001, roughly five months after the beginning of the Campaign.

Table 4 compares the numbers of diabetes-related tests performed monthly during the Campaign (March through May 2001) and during the same 3 months one year earlier. For the 12 months of 2001 compared with the 12 months of 2000, the mean (and standard deviation) of diabetesrelated tests performed monthly increased from 8300 (2 200) to 9100 (900) for the glucose tolerance test, from 1700700 (86 800) to 1830100 (92 500) for the serum glucose test, and from 46400 (4 300) to 57700 (4 500) for the glycated hemoglobin test.

\section{DISCUSSION}

The participation rate in the National Campaign to Detect Suspected Cases of Diabetes Mellitus was high, and the absolute number of tests performed was vast. Of the 22.1 million persons tested, a total of 3.5 million of them (16\%) had positive results. Vaccination campaigns in Brazil have played a role in eradicating smallpox and polio, in dramatically decreasing the incidence of measles and rubella, and in reducing the morbidity and mortality from other vaccinepreventable diseases. Given that rec- 
TABLE 2. Characteristics of the 5301 municipalities participating in the National Campaign to Detect Suspected Cases of Diabetes Mellitus, Brazil, 2001

\begin{tabular}{|c|c|c|}
\hline \multirow[b]{2}{*}{ Category/Characteristic } & \multicolumn{2}{|c|}{ Municipalities } \\
\hline & No. & $\%$ \\
\hline \multicolumn{3}{|l|}{ Region } \\
\hline Center-West & 426 & 8.0 \\
\hline North & 417 & 7.9 \\
\hline Northeast & 1688 & 31.8 \\
\hline Southeast & 1640 & 30.9 \\
\hline South & 1130 & 21.3 \\
\hline \multicolumn{3}{|c|}{ Extent of health care services managed by the municipal level } \\
\hline Not specified & 153 & 2.9 \\
\hline Outpatient care only & 4674 & 88.2 \\
\hline All care & 474 & 8.9 \\
\hline \multicolumn{3}{|c|}{ Proportion of population registered in Family Health Program } \\
\hline$<50 \%$ & 811 & 15.3 \\
\hline$\geq 50 \%$ & 458 & 8.6 \\
\hline None & 4032 & 76.1 \\
\hline \multicolumn{3}{|c|}{ Proportion of population registered in Community Health Agents Program } \\
\hline$<50 \%$ & 1124 & 21.2 \\
\hline$\geq 50 \%$ & 1250 & 23.6 \\
\hline None & 2927 & 55.2 \\
\hline \multicolumn{3}{|l|}{ Located in metropolitan region } \\
\hline Yes & 445 & 8.4 \\
\hline No & 4856 & 91.6 \\
\hline \multicolumn{3}{|l|}{ Proportion of population living in urban area } \\
\hline$<25 \%$ & 428 & 8.1 \\
\hline$\geq 25 \%$ to $<75 \%$ & 3280 & 61.9 \\
\hline$\geq 75 \%$ & 1593 & 30.1 \\
\hline \multicolumn{3}{|l|}{ Proportion of population who completed elementary schoola } \\
\hline$<5 \%$ & 1256 & 26.2 \\
\hline$\geq 5 \%$ to $<10 \%$ & 1738 & 36.2 \\
\hline$\geq 10 \%$ & 1807 & 37.6 \\
\hline \multicolumn{3}{|l|}{ Total population } \\
\hline$<50000$ & 4783 & 90.2 \\
\hline$\geq 50000$ to $<100000$ & 295 & 5.6 \\
\hline$\geq 100000$ to $<500000$ & 192 & 3.6 \\
\hline$\geq 500000$ & 31 & 0.6 \\
\hline
\end{tabular}

a Source: Instituto Brasileiro de Geografia e Estatística, 1996, 4801 municipalities.

ord of success, it is not surprising that a campaign approach was chosen as the rallying point for the national program to restructure primary care level management of diabetes and hypertension. The result was a major accomplishment in terms of mobilizing the population.

There was a noticeable range in the participation rates among the Brazilian municipalities. The municipality characteristics that were significantly related to a high participation rate were: a smaller total population, a smaller proportion of the population living in an urban area, a higher level of schooling among the residents, and a location outside of a metropolitan re- gion. Municipalities located in the North region also generally showed higher participation rates.

Two of the Brazilian states, Pará and Rio Grande do Norte, had participation rates higher than $100 \%$. There are several possible explanations for this finding: more than $75 \%$ of the population utilize the UHS in these states, which are relatively poor; subjects less than 40 years of age were tested; or adults, including those with known diabetes, repeated the test during the Campaign.

We found that smaller municipalities had higher participation rates. This may reflect the fact that, despite being less economically advanced, they are able to mobilize the population more quickly. In addition, in these municipalities the UHS provides services for a larger proportion of the residents. These municipalities may also face a greater burden of communicable, maternal, and childhood diseases and so have most sensed the benefit of earlier campaigns and other organized public health measures. In addition, the citizens of these municipalities may have fewer alternatives for diabetes testing.

The Campaign instructions did not mandate immediate follow-up testing for all the persons who had positive 
TABLE 3. Municipality characteristics associated with a high participation rate in the National Campaign to Detect Suspected Cases of Diabetes Mellitus, with risk ratio (RR) and 95\% confidence interval (95\% Cl), Brazil, 2001

\begin{tabular}{|c|c|c|c|c|}
\hline \multirow[b]{3}{*}{ Characteristic/Category } & \multicolumn{4}{|c|}{ Relative risk } \\
\hline & \multicolumn{2}{|c|}{ Crude } & \multicolumn{2}{|c|}{ Adjusted } \\
\hline & $\mathrm{RR}$ & $95 \% \mathrm{Cl}$ & $\mathrm{RR}$ & $95 \% \mathrm{Cl}$ \\
\hline \multicolumn{5}{|l|}{ Region } \\
\hline Center-West & \multicolumn{2}{|c|}{ Reference } & \multicolumn{2}{|c|}{ Reference } \\
\hline North & 1.7 & $1.4-2.0$ & 1.8 & $1.5-2.2$ \\
\hline Northeast & 1.1 & $0.9-1.3$ & 1.2 & $0.9-1.4$ \\
\hline Southeast & 0.9 & $0.8-1.1$ & 0.9 & $0.7-1.1$ \\
\hline South & 1.0 & $0.8-1.2$ & 1.0 & $0.8-1.2$ \\
\hline \multicolumn{5}{|c|}{ Extent of health care services managed by the municipal level } \\
\hline Not specified & \multicolumn{2}{|c|}{ Reference } & \multicolumn{2}{|c|}{ Reference } \\
\hline Outpatient care only & 0.7 & $0.6-0.8$ & 1.1 & $0.9-1.4$ \\
\hline All care & 0.9 & $0.6-1.2$ & 0.8 & $0.5-1.1$ \\
\hline \multicolumn{5}{|c|}{ Proportion of population registered in Family Health Program } \\
\hline$<50 \%$ & \multicolumn{2}{|c|}{ Reference } & \multicolumn{2}{|c|}{ Reference } \\
\hline$\geq 50 \%$ & 0.8 & $0.7-0.9$ & 1.0 & $0.8-1.1$ \\
\hline None & 1.2 & $1.0-1.4$ & 1.1 & $0.9-1.4$ \\
\hline \multicolumn{5}{|c|}{ Proportion of population registered in Community Health Agents Program } \\
\hline$<50 \%$ & \multicolumn{2}{|c|}{ Reference } & \multicolumn{2}{|c|}{ Reference } \\
\hline$\geq 50 \%$ & 0.7 & $0.6-0.8$ & 0.7 & $0.6-0.8$ \\
\hline None & 1.1 & $1.0-1.3$ & 1.0 & $0.8-1.1$ \\
\hline \multicolumn{5}{|l|}{ Located in metropolitan region } \\
\hline Yes & \multicolumn{2}{|c|}{ Reference } & \multicolumn{2}{|c|}{ Reference } \\
\hline No & 1.8 & $1.4-2.2$ & 1.4 & $1.1-1.8$ \\
\hline \multicolumn{5}{|l|}{ Proportion of population living in urban area } \\
\hline$<25 \%$ & 1.5 & $1.2-1.8$ & 1.3 & $1.0-1.6$ \\
\hline$\geq 25 \%$ to $<75 \%$ & 1.5 & $1.3-1.6$ & 1.2 & $1.0-1.4$ \\
\hline$\geq 75 \%$ & \multicolumn{2}{|c|}{ Reference } & \multicolumn{2}{|c|}{ Reference } \\
\hline \multicolumn{5}{|c|}{ Proportion of population that completed elementary school ${ }^{a}$} \\
\hline$<5 \%$ & \multicolumn{2}{|c|}{ Reference } & \multicolumn{2}{|c|}{ Reference } \\
\hline$\geq 5 \%$ to $<10 \%$ & 1.1 & $0.9-1.2$ & 1.2 & $1.1-1.4$ \\
\hline$\geq 10 \%$ & 0.8 & $0.7-0.9$ & 1.2 & $1.0-1.5$ \\
\hline \multicolumn{5}{|l|}{ Total population } \\
\hline$<50000$ & \multicolumn{2}{|c|}{ Reference } & \multicolumn{2}{|c|}{ Reference } \\
\hline$\geq 50000$ to $<100000$ & 0.4 & $0.3-0.5$ & 0.4 & $0.3-0.6$ \\
\hline$\geq 100000$ to $<500000$ & 0.3 & $0.2-0.5$ & 0.4 & $0.2-0.6$ \\
\hline$\geq 500000$ & 0.1 & $0.0-0.8$ & 0.2 & $0.0-1.1$ \\
\hline
\end{tabular}

${ }^{a}$ Full model includes all variables in the table.

screening results. The recommendations were for those with a glucose value of $\geq 270 \mathrm{mg} / \mathrm{dL}$ to be immediately referred for management, and for those with a fasting value $\geq 126 \mathrm{mg} / \mathrm{dL}$ or a casual value $\geq 200 \mathrm{mg} / \mathrm{dL}$ to be immediately scheduled for confirmatory testing. Persons with lower screen-positive values were scheduled for a follow-up consultation three months later, without a specific indication of the need for further lab testing. Preliminary estimates (22) suggest that approximately $22 \%$ of the 3.5 million positive tests were in the $\geq 126 \mathrm{mg} / \mathrm{dL}$ range for fasting participants or the $\geq 200 \mathrm{mg} / \mathrm{dL}$ range for participants with nonfasting values. There was a net increase of about 750000 fasting glucose tests carried out in the country from March to May of 2001 over the number performed in the same three months the year before, suggesting a vigorous response to the Campaign. To the extent that increased testing could also be for subsequent case management, and not for diagnostic confirmation, this number overestimates the possible impact of the screening. To the extent that diagnostic testing was performed at hospitals or private laboratories or with surplus glucose meter testing strips remaining from the Campaign, the number of outpatient tests related through the DATASUS database underestimates the degree of confirmatory testing. In any case, there was an increase in glycated hemoglobin tests (used to assess diabetes control) that paralleled the increase in venous glucose tests. This indicates that the impact of the Campaign went beyond mere diagnosis.

There were some limitations to our evaluation of this massive Campaign. 
FIGURE 1. Number of serum glucose and glycated hemoglobin tests performed per month in outpatient laboratories affiliated with the Brazilian Unified Health System, January 2000 to December 2001

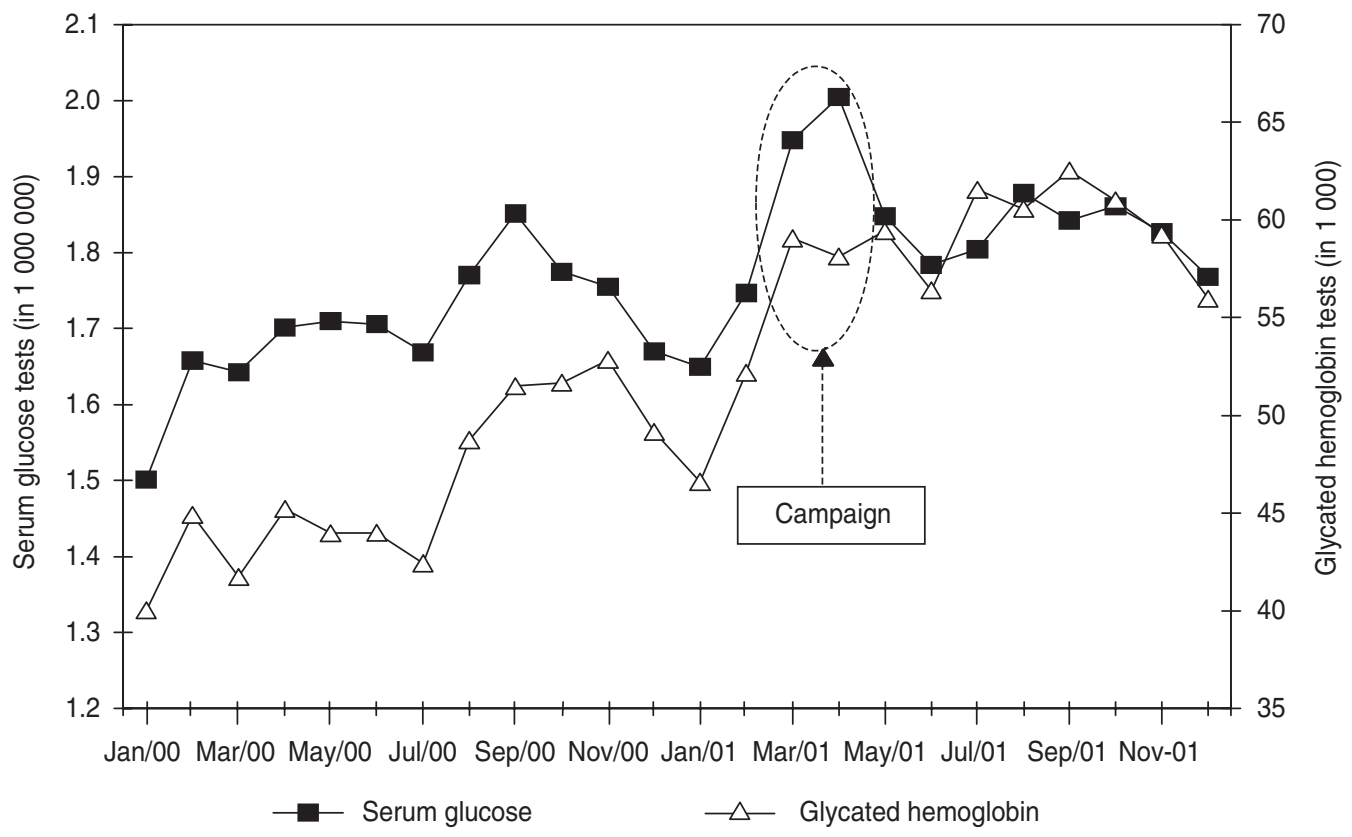

TABLE 4. Mean number (and standard deviation (SD)) of selected laboratory exams performed per month in outpatient laboratories affiliated with the Brazilian Unified Health System in the three months around the time of the National Campaign to Detect Suspected Cases of Diabetes Mellitus (March-May 2001) versus a year earlier

\begin{tabular}{|c|c|c|c|c|c|c|}
\hline \multirow[b]{3}{*}{ Laboratory exam } & \multicolumn{4}{|c|}{ Tests (1 000/month) } & \multirow{3}{*}{$\begin{array}{l}\text { Increase } \\
\text { in number } \\
\text { of tests }\end{array}$} & \multirow[b]{3}{*}{$P$ value } \\
\hline & \multicolumn{2}{|c|}{$\begin{array}{c}1 \text { year prior to the } \\
\text { Campaign } \\
\text { (Mar-May 2000) }\end{array}$} & \multicolumn{2}{|c|}{$\begin{array}{l}\text { Around the time } \\
\text { of the Campaign } \\
\text { (Mar-May 2001) }\end{array}$} & & \\
\hline & Mean & SD & Mean & SD & & \\
\hline Serum glucose & 1684.5 & 36.7 & 1933.3 & 79.3 & 248.8 & 0.018 \\
\hline Glucose tolerance test & 8.2 & 1.7 & 9.4 & 0.5 & 1.2 & 0.333 \\
\hline Glycated hemoglobin & 43.7 & 1.8 & 58.9 & 0.7 & 15.2 & 0.002 \\
\hline
\end{tabular}

a Increase in number of tests = Campaign monthly mean (March-May 2001) minus monthly mean during the same period one year prior to the Campaign (MarchMay 2000).

Our data were secondary in nature, having been collected by national Ministry of Health for the operational follow-up to the campaign. Therefore, the assessment of the diagnostic impact is indirect and preliminary in nature. Participation and positivity rates are undoubtedly somewhat inflated by the inclusion of some cases of previously diagnosed diabetes and some cases of repeated screenings. Additional studies, based on follow-up of screen-positive individuals, will address these issues in a more direct form, so as to evaluate the effectiveness and cost-effectiveness of the Campaign. What merits emphasis here is the massive response to this screening program. This response attests to the potential that this type of campaign has to raise population awareness of diabetes and to set the stage for capacity-building for diabetes management at the primary care level.

Acknowledgments. This study was supported by Health Policy Division, Ministry of Health, Brazil. 


\section{REFERENCES}

1. King H, Aubert RE, Herman WH. Global burden of diabetes, 1995-2025. Diabetes Care. 1998;21:1414-31.

2. Narayan KM, Gregg EW, Fagot-Campagna A, Engelgau MM, Vinicor F. Diabetes-a common, growing, serious, costly, and potentially preventable public health problem. Diabetes Res Clin Pract. 2000;50 Suppl 2:S77-S84.

3. World Health Organization. Definition, diagnosis and classification of diabetes mellitus and its complications. Report of a WHO consultation. Part 1: diagnosis and classification of diabetes mellitus. Geneva; WHO; 1999. (WHO/NCD/NCS/99.2).

4. Malerbi DA, Franco LJ. Multicenter study of the prevalence of diabetes mellitus and impaired glucose tolerance in the urban Brazilian population aged 30-69 yr. The Brazilian Cooperative Group on the Study of Diabetes Prevalence. Diabetes Care. 1992;15(11):150916.

5. Engelgau MM, Narayan KM, Herman WH. Screening for type 2 diabetes. Diabetes Care. 2000;23(10):1563-80.

6. Wareham NJ, Griffin SJ. Should we screen for type 2 diabetes? Evaluation against National Screening Committee criteria. BMJ. 2001;322 (7292):986-8.

7. American Diabetes Association and National Institute of Diabetes, Digestive and Kidney Diseases. The prevention or delay of type $2 \mathrm{di}-$ abetes. Diabetes Care. 2002;25:742-9.

8. Harris MI, Eastman RC. Early detection of undiagnosed diabetes mellitus: a US perspective. Diabetes Metab Res Rev. 2000;16:230-6.
9. American Diabetes Association. Report of the Expert Committee on the Diagnosis and Classification of Diabetes Mellitus. Diabetes Care. 2002;25 Suppl 1:S5-20.

10. World Health Organization. Screening for type 2 diabetes. Report of a World Health Organization and International Diabetes Federation meeting. Geneva: WHO; 2003. (WHO/ $\mathrm{NMH} / \mathrm{MNC}$ /03.1)

11. Brasil, Secretaria de Políticas Públicas/Ministério da Saúde. Plano de Reorganização da Atenção à Hipertensão Arterial e ao Diabetes Mellitus. Rev Saude Publica. 2001;35(6):585-8.

12. Brasil, Secretaria de Políticas Públicas/Ministério da Saúde. Plano de Reorganização da Atenção à Hipertensão Arterial e ao Diabetes Mellitus: fase de detecção de casos suspeitos de DM. Rev Saude Publica. 2001;35(5):490-3.

13. Barbosa RB, Barceló A, Machado CA. Campanha nacional de detecção de casos de diabetes mellitus no Brasil: relatório preliminar. Rev Panam Salud Publica. 2001;10(5):324-7.

14. DATASUS. Informações de saúde -informações demográficas e socioeconômicas / população residente de 1980 a 2003. Available from: http://tabnet.datasus.gov.br/cgi/ ibge/popmap.htm. Accessed 21 July 2003.

15. DATASUS. Informações de saúde - assistência à saúde / PSF-Programa de Saúde da Família. Available from: http://tabnet.datasus. gov.br/cgi/siab/psfmap.htm. Accessed 21 July 2003.

16. DATASUS. Informações de saúde - assistência à saúde / PACS-Programa de Agentes Comunitários da Saúde. Available from: http:/ / tabnet.datasus.gov.br/cgi/siab/pacsmap $\mathrm{htm}$. Accessed 21 July 2003.

17. DATASUS. Arquivos - arquivos de dados / tabelas de unidades territoriais. Available from: http://www.datasus.gov.br/municip/ arqcnv.htm. Accessed 23 July 2003.

18. DATASUS. Informações de saúde - informações demográficas e socioeconômicas / escolaridade. Available from: http://tabnet. datasus.gov.br/cgi/ibge/estmap.htm. Accessed 21 July 2003.

19. DATASUS. Informações de saúde - assistência à saúde / produção ambulatorial. Available from: http://tabnet.datasus.gov.br/cgi/ sia/pamap.htm. Accessed 14 July 2003.

20. SAS Institute. SAS/STATTM guide for personal computers. 6th ed. Cary: SAS Institute Inc.; 1998.

21. Zhang J, Yu KF. What's the relative risk?: a method of correcting the odds ratio in cohort studies of common outcomes. JAMA. 1998; 280(19):1690-1.

22. Brasil, Ministério da Saúde; Organização PanAmericana da Saúde. Relatório: avaliação do Plano de Reorganização da Atenção à Hipertensão Arterial e ao Diabetes Mellitus no Brasil. Brasília: Ministério da Saúde; 2004.

Manuscript received 28 October 2003. Revised version accepted for publication 28 July 2004.

RESUMEN Objetivos. En 2001, se invitó a los habitantes del Brasil de 40 años de edad o mayores a participar en un programa para el tamizaje de la diabetes sacarina como parte del Plan de Reorganización de la Atención de la Hipertensión Arterial y la Diabetes Mellitus, del Ministerio de Salud del Brasil. En este informe se describen los porcentajes totales de participación y de resultados positivos obtenidos en la campaña de tamizaje, así como los factores asociados con el grado de participación en las distintas municipalidades del Brasil.

Métodos. Se definió como resultado positivo una glucemia en ayunas $=100 \mathrm{mg} / \mathrm{dL}$ o una glucemia casual $=140 \mathrm{mg} / \mathrm{dL}$. Los resultados del tamizaje se obtuvieron del Ministerio de Salud y se analizaron por municipalidad.

Resultados. De las 5561 municipalidades del Brasil, 5301 (95,3\%) participaron y notificaron los resultados. De los 30,2 millones de personas que integraban la población destinataria, 22,1 millones (73,0\%) recibieron la prueba, y de estas últimas, 3,5 millones $(15,7 \%)$ tuvieron resultados positivos. Las probabilidades de un buen porcentaje de participación $(\geq 80 \%$ ) fueron mayores en las municipalidades pequeñas (razón de riesgos $(R R)=5,0$, al compararse los valores extremos), en las situadas en la parte norte del país $(R R=1,8)$, en las ubicadas a las afueras de una zona metropolitana $(R R=1,4)$ y en aquellas donde era mayor el porcentaje de la población que había completado la escuela primaria $(R R=1,2)(P<0,05)$. En todo el país aumentó el uso de la prueba de glucosa inmediatamente después de la campaña, quizá debido en parte a la necesidad de confirmar el diagnóstico de los casos identificados mediante el tamizaje.

Conclusiones. La respuesta entusiasta a la campaña ilustra que este tipo de programa puede servir para crear mayor conciencia en torno al problema de la diabetes y para sentar las bases del fortalecimiento de la capacidad en el contexto de la atención primaria de salud. 